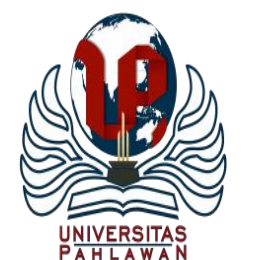

Edukatif : Jurnal Ilmu Pendidikan Volume 2 Nomor 2 Tahun 2020 Halm 121-127

EDUKATIF: JURNAL ILMU PENDIDIKAN

Research \& Learning in Education

https:/ledukatif.org/index.php/edukatif/index

\title{
Analisis Kebijakan Dan Pengelolaan Pendidikan Dasar terkait Standar Isi Di Sekolah Dasar
}

\author{
Fatma Khaulani ${ }^{1}$, Sufyarma Marsidin ${ }^{2}$, Ahmad Sabandi ${ }^{3}$ \\ Universitas Negeri Padang, Sumatera Barat, Indonesia ${ }^{1,2,3}$ \\ E-mail : fatmakhaulani25@gmail.com ${ }^{1} \underline{\text { sufyarma1954@gmail.com }}{ }^{2}$ sabandi@fip.unp.ac.id ${ }^{3}$
}

\begin{abstract}
Abstrak
Artikel ini menganalisis kebijakan dan pengelolaan pendidikan mengenai standar isi di sekolah dasar berdasarkan Permen No 21 Tahun 2016 mengenai standar isi di SD. Berdasarkan penelitian yang dilakukan melalui kajian pustaka. Standar isi ialah suatu ruang lingkup materi yang menyediakan pengalaman bagi pesertadidik untuk belajar guna memberikan peningkatan pengetahuan dan keterampilan yang sesuai dengan kebutuhan lingkungan. Standar Isi mencapai tujuan yang merangkap keseluruhan yang merangkup berbagai aspek yang hendak dipenuhi serta menjadi pengalaman belajar siswa. Tujuan dijabarkan secara universal sebagai sasaran hasil atau tujuan yang hendak didapatkan peserta didik. Sasaran pada kurikulum 2013 dijabarkan dalam SKL, tujuan dijabarkan dalam Standar Isi yang merupakan turunan dari SKL terdiri KI dan KD, dan program pendidikan yang objektif dituangkan dalam Standar Proses dan Standar Penilaian.
\end{abstract}

Kata kunci: standar, isi, sekolah dasar

\begin{abstract}
This article analyzes the policies and management of education regarding content standards in elementary schools based on candy no 212016 on content standards in elementary schools. Based on research conducted through literature review, the content standard is a scope of material that provides learning experiences for students in order to improve their knowledge and skills in accordance with environmental needs. The Content Standards achieve goals that are concurrently composed of various aspects that will be achieved and become students' learning experiences. the goal is generally described as the target outcome or thing the student wants to achieve. The targets in the 2013 curriculum are outlined in the SKL, the objectives are stated in the Content Standards which are derived from SKL consisting of KI and KD, and objective educational programs are outlined in the Process Standards and Assessment Standards.
\end{abstract}

Keywords: standard, content, primary school

Copyright (c) 2020 Fatma Khaulani, Suryarma Marsidin, Ahmad Sabandi

$\triangle$ Corresponding author:

Address :

Email : fatmakhaulani25@gmail.com

ISSN 2656-8071 (Media Cetak)

Phone :

ISSN 2656-8063 (Media Online)

DOI: $10.31004 /$ edukatif.v2i2.112 
122 Analisis Kebijakan Dan Pengelolaan Pendidikan Dasar terkait Standar Isi Di Sekolah Dasar - Fatma Khaulani, Sufyarma Marsidin, Ahmad Sabandi

DOI: $10.31004 /$ edukatif.v2i2.112

\section{PENDAHULUAN}

Pendidikan memberikan dampak besar pada kemajuan suatu bangsa, dan juga bertindak sebagai suatu tempat guna mengartikan pesan-pesan konstitusi serta wahana guna mengupayakan kegiatan membentuk karakter nasional. Suatu golongan masyarakat yang cerdas tentu memberi spektrum kehiduan yang cerdas pula, dan dengan sendirinya dengan bertahap akan membentuk kemandirian. Masyarakat yang bisa berperilaku sesuai dengan hal tersebut merupakan investasi berharga guna menghadapi krisis dan menghadapi dunia global (Haq, 2017).

Kebutuhan akan pendidikan yang layak, yang tidak sekedar melaksanakan pendidikan sebagai bentuk melepaskan tanggung jawab melainkan pendidikan yang bertujuan untuk membentuk dan mengarahkan peserta didik dengan memberikan dan melengkapi fasilitas pendidikan itu sendiri adalah bagian terpenting dalam mengisi kemerdekaan Bangsa Indonesia semenjak jenjang SD hingga perguruan tinggi. Hal menjadi perhatian kita semua adalah bagaimana bangsa Indonesia terutama pemerintah dalam upaya menghadirkan pendidikan terutama pendidikan dasar yang menjadikan patokan akan kesuksesan peserta didik pada jenjang selanjutnya sehingga mampu menghasilkan peserta didik yang akan menjadi aktor utama pada 15 tahun yang akan mendatang. Pendidikan yang bermutu dapat melahiran manusia yang bermutu pula (Widodo, 2015), yang akan menentukan keberhasilan pembangunan bangsa (Kemenkeu, 2017).

Bangsa Indonesia menjadi perhatian dunia pada masa sekarang. Karena pada tahun 2035-
2045 adalah masa Indonesia mendapatkan bonus geografis, dimana 60\% jumlah penduduk yang berusia dibawah 30 tahun lebih banyak (Kemenkeu, 2017). Dalam memanfaat bonus demografi Indonesia harus merencanakan pendidikan dasar yang tepat dengan memperhatikan dan menentukan kebutuhan 15 tahun yang akan mendatang, bila perencanaan tersebut tidak diperhatikan maka bonus geografis tersebut menjadi beban bagi bangsa Indonesia karena jumlah pengangguran akan meningkat.

Agenda besar bangsa Indonesia saat ini adalah bagaimana mutu pendidikan bisa setara dengan bangsa lain di Asia bahkan dunia (Riyana, 2010). Upaya yang bisa dilakukan dalam mencapai masa gemilang tersebut adalah pembaharuan pada standar isi pendidikan Indonesia, yang telah dilakukan pemerintah pada beberapa tahun setelah perubahan kurkulum dari KTSP menjadi kurikulum 2013, berupa Permendiknas No. 21 Tahun 2016 tentang Standar Isi Dekdasmen yang berisikan ketentuan dalam pencapaian standar isi sesuai dengan Kurikulum 2013.

Sebagai calon pendidik dan ahli bidang pendidikan dasar menjadi tanggung jawab bersama untuk mengkaji isi dari Permendiknas No. 21 tahun 2016 tentang Standar Isi Dekdasmen terutama pada jenjang pendidikan sekolah dasar, agar isi standar pendidikan sekolah dasar yang direncanakan tidak sekedar konsep yang tidak dapat diterapkan dengan kondisi realita pendidikan dilapangan yang memiliki permasalahan yang kompleks. 
123 Analisis Kebijakan Dan Pengelolaan Pendidikan Dasar terkait Standar Isi Di Sekolah Dasar - Fatma Khaulani, Sufyarma Marsidin, Ahmad Sabandi

DOI: $10.31004 /$ edukatif.v2i2.112

\section{METODE PENELITIAN}

Tulisan ini menggunakan studi perpustakaan (library research) sebagai metode penelitiannya. Studi kepustakaan identik dengan pengumpulan data dari berbagai sumber bacaan. Buku, jurnal, maupun artikel ,merupakan bahan bacaan yang menjadi sumber data dalam penelitian ini.

\section{HASIL DAN PEMBAHASAN PENELITIAN}

\section{Permendiknas No. 21 tahun 2016 tentang Standar Isi di Sekolah Dasar}

Standar isi dalam suatu kurikulum merupakan cakupan minimum dalam suatu kurikulum yang sedang digunakan secara nasional. (Permendikanas no 21, 2016).

Dilihat dari aspek general, standar isi meliputi karangka dasar kurikulum, struktur kurikulum, dan karakteristik kurikulum 2013. Pada ketiga karakteristik tersebut struktur kurikulum menjadi bahasan yang menarik. Struktur kurikulum 2013 tidaklah sama dengan struktur kurikulum sebelumnya. SKL (Standar Kompetensi Lulusan) dijabarkan menjadi kompetensi inti (KI) terlebih dulu. Kompetensi inti (KI) merupakan penjabaran dari standar kompetensi. Oleh standar kompetensi pada kurikulum 2013 dileburkan ke dalam kompetensi inti atau dapat dikatakan bahwa standar isi dalam kurikulum 2013 diperoleh dari standar kompetensi lulusan melalui kompetensi inti yang bebas mata pelajaran. Kompetensi inti di desain sedemikan rupa sesuai dengan tahap perkemabangan usia peserta didik di suatu kelas (Oktaviani, 2019).

Standar isi dalam suatu kurikulum mempunyai tujuan yaitu:
1. Menyokong pendidikan untuk membangun serta mengidentifikasi suatu hal yang menjadi poin penting yang akan diajarkan di sekolah dan apa yang menjadi aktifitas yang akan peserta didik kerjakan

2. Standar isi menjadi sebuah panduan dalam pembelajaran, kurikulum dan penilaian yang bermakna

3. Standar isi dapat menyediakan struktur yang jelas bagi pembelajaran dan kurikulum (Oktaviani, 2019)

Penetapan Permendiknas No. 21 tahun 2016 tentang standar isi adalah penjabar dari UU No. 20 tahun 2003 tentang Sisdiknas merupakan upaya memenuhi kebutuhan dan mempersiapkan genarasi emas Indonesia Tahun 2045, melalui penetapan standar pendidikan berbasis pada kompetensi abad 21. Satuan pendidikan dalam jenjang dan jenis pendidikan tertentu harus memenuhi materi dan tingkat kompetensi peserta didik yang ditetapkan dalam standar isi pada mata pelajaran.

Sikap menerima, menghargai menjalankan, menghayati, serta mengamalkan merupakan sikap yang dijalankan melalui aktivitas-aktivitas guna mencapai standar isi. Sedangkan pengetahuan didapat dari aktifitas mengetahui, memahami, menerapkan, menganalisis, mengevaluasi, serta mencipta, serta keterampilan diperoleh melalui aktivitas mengamati, menanya, mencoba, menalar, menyaji, dan mencipta. Standar isi dipengaruhi oleh karakteristik kompetensi perbedaan proses pemerolehannya.

PP No 19 Tahun 2005 mengenai penetapan standard isi sebagai barometer ruang lingkup materi dan tingkat kompetensi guna mencapai 
124 Analisis Kebijakan Dan Pengelolaan Pendidikan Dasar terkait Standar Isi Di Sekolah Dasar - Fatma Khaulani, Sufyarma Marsidin, Ahmad Sabandi

DOI: 10.31004/edukatif.v2i2.112

kompetensi lulusan pada suati tingkatan dan jenis pendidikn tertentu.

Berdasarkan pertimbangan yang telah dijabarkan, Tingkat Kompetensi dirumuskan sebagai berikut:

Tabel 1. Tingkat Kompetensi Anak

\begin{tabular}{|c|c|l|}
\hline No. & \multicolumn{1}{|c|}{ Tingkat Kompetensi } & \multicolumn{1}{|c|}{ Jenjang pendidikan } \\
\hline 1. & Tingkat Pendidikan Anak & TKRA \\
\hline 2. & Tingkat Pendidikan Dasar & SDMISDLBP Paket A \\
\cline { 3 - 3 } 4. & SMPMMTS SMPLBP Paket B \\
\hline
\end{tabular}

\section{Keterangan:}

SDLB, SMPLB, dan SMALB ditetapkan untuk tuna netra, tuna rungu, tunadaksa, dan tuna laras yang kemampuan memecahkan masalah serta mampu beradaptasi dengan lingkungkan yang normal.

Taksonomi bloom pengembangan Anderson dan Krathwol pada tahun 2001 menjadi tumpuan SKL. Taksonomi bloom mengelompokkan hasil akhir pembelajaran menjadi tiga ranah, yaitu pengetahuan, sikap dan ketrampilan. Untuk dimensi pengetahuan dikategorikan menjadi faktual, konseptual, prosedural, serta metakognitif yang penguasaannya yang dimulai sejak tingkt SD sampai tingkat menengah.

\section{Structure of Observed Learning Outcome} (SOLO) merupakan klasifikasi bidang ilmu yang pada awalnya dicetuskan oleh Biggs dan Collin (1982) dan pada tahun 2003 mendapatkan pembaharuan konsep. SOLO dimanfaatkan sebagai pijakan dalam mengklasifikasikan tingkat kompetensi untuk aspek kognitif. Menurut SOLO setiap bidang ilmu mempunyai lima sintaks yang akan dilewati oleh setiap peserta didik untuk menguasai suatu pengetahuan, terdiri dari tahap pre-struktural, unistruktural, multi struktural, relasional serta abstrak yang diperluas. Tahapan ini dimodifikasi menjadi tiga, yaitu surface knowledge, deep knowledge dan constructed knowledge. Tahap surface knowledge didapatkan pada tingkat pendidikan dasar tepatnya pada masa $\mathrm{SD}$, tahap deep knowledge diperoleh pada tingkat pendidikan dasar pada masa SMP dan tahap conceptual/constructed knowledge didapatkan pada tingkat menengah yaitu pada tingkat SMA. Akan tetapi, pada jenis pengetahuan tertentu, ketiga tahap ini dapat diperoleh dalam satu jenjang pendidikan atau dalam satu tingkat kelas.

SKL merupakan acuan menetapkan kompetensi yang bersifat universal yang kemudian digunaka menetapkan kompetensi yang bersifat spesifik. Kompetensi dari lingkup materi digunakan untuk menetapkan KD pada pengembangan kurikulum tingkat satuan dan jenjang pendidikan.

Kompetensi yang memiliki sifat universal melinkkupi tiga dimensi yakni sikap, pengetahan serta keterampilan. Dimensi sikap diklasifikasikan menjadi sikap spiritual dan sikap sosial. Dengan demikian, kompetesi yang bersifat universal terdiri atas empat dimensi yang merepesentasikan sikap spiritual, sikap sosial, pengetahuan, dan keterampilan, yang kemudian dikenal sebagai Kompetensi Inti (KI). Semakin tinggi Tingkat Kompetensi, semakin komleks pengalaman belajar siswa, proses pembelajaran serta penilaian. 
125 Analisis Kebijakan Dan Pengelolaan Pendidikan Dasar terkait Standar Isi Di Sekolah Dasar - Fatma Khaulani, Sufyarma Marsidin, Ahmad Sabandi

DOI: $10.31004 /$ edukatif.v2i2.112

Kompetensi inti dari setiap kompetensi dijabarkakan dalam tabel berikut:

Tabel 2. Deskripsi Kompetensi Inti

\begin{tabular}{|c|c|}
\hline $\begin{array}{l}\text { KOPETENSI } \\
\text { INTI }\end{array}$ & DESKRIPSI KOPETENSI \\
\hline Sikap Spritual & $\begin{array}{l}\text { 1. Menerima, menialankan, dan menghargai ajaran agama } \\
\text { yang dianutnva. }\end{array}$ \\
\hline Sikap Sosial & $\begin{array}{l}\text { 2. Menuniukkan perilaku: } \\
\text { (a) jujur, } \\
\text { (b) disiplin, } \\
\text { (c) santun, } \\
\text { (d) percaya diri, } \\
\text { (e) peduli, dan } \\
\text { (f) bertanggung jawab } \\
\text { dalam berinteraksi dengan keluarga, teman, guru, dan } \\
\text { tetangga, dan negara }\end{array}$ \\
\hline Pengetahuan & $\begin{array}{l}\text { 3. Memahami pengetahuan faktual, konseptual, prosedural } \\
\text { dan metakognitif pada tingkat dasar dengan cara: } \\
\text { (a) Mengamati. } \\
\text { (b) Menanya, dan } \\
\text { (c) Mencoba } \\
\text { Berdasarkan rasa ingin tahu tentang dirinya, makhluk } \\
\text { ciptaan Tuhan dan kegiatannya, dan benda-benda yang } \\
\text { dijumpainva di numah, di sekolah, dan tempat bermain. }\end{array}$ \\
\hline Keterampilan & $\begin{array}{l}\text { 4. Menunjukkan keterampilan berfikir dan bertindak: } \\
\text { (a) Kreatif } \\
\text { (b) Produktif } \\
\text { (c) Kritis } \\
\text { (d) Mandiri } \\
\text { (e) Kolaboratif, dan } \\
\text { (f) Komunikatif } \\
\text { Dalam bahasa yang jelas, sistematis, logis dan knitis, dalam } \\
\text { karya yang estetis, dalam gerakan yang mencerminkan anak } \\
\text { sehat, dan tindakan yang menceminkan perilaku anak } \\
\text { sesuai dengan tahap perkembangannya. }\end{array}$ \\
\hline
\end{tabular}

Pandangan tentang berlakunya Permendiknas No. 21 tahun 2016 tentang Standar Isi Dekdasmen terutama sekolah dasar.

Standar pendidikan isi Indonesia telah beberapa kali mengalai perubahan baik dalam jangka waktu yang jauh maupun pada waktu yang dekat. Hal tersebut menunjukkan bahwa perencanaan dan penentuan akan kebutuhan pendidikan dimasa depan belum dapat dilaksanakan dengan baik, karena setiap Standar Isi Pendidikan Nasional Indonesia belum dapat dicapai, namun telah mengalami perubahan. Pada salinan Permendiknas No. 21 Tahun 2016 bersisikan beberapa taksonomi yang dijadikan rujukan dalam mencapai standar kelulusan, tanpa mengikutsertakan sertai karakteristik sosial budaya asli bangsa Indonesia.

Standar isi pendidikan di Indonesia akan dinyatakan efektif jika pendidikan dapat menghasilkan generasi bangsa yang sesuai dengan kebutuhan zaman sekarang dan 15-20 tahun selanjutnya. Standar isi pendidikan Indonesia belum mampu memberikan ruang antara kesesuaian isi pendidikan dengan realita pendidikan di lapangan. Hal tersebut menunjukkan pendidikan Indonesia belum mampu bersaing sepenuhnya dengan negara-negara yang telah berhasil memajukan bidang pendidikannya.

Perubahan standar isi yang terjadi belum sepenuhnya mampu menghasilkan perubahan yang signifikan dalam pendidikan bangsa, banyak wacana yang disampaikan dalam memperbaharui pendidikan, salah satunya mengenai standar isi yang ada. Namun ketidaksesuaian standar isi dengan realita yang terjadi dapat menyebabkan tidak tercapainya tujuan pendidikan nasional secara baik. Penting menjadi perhatian adalah dalam beberapa tahun belakang pendidikan kita tidak lagi mengembangkan pendapat para putra dan putri bangsa seperti pendapat Khi Hajar dewantara, Ahmad Dahlan, dan lain-lain, jika pun ada ruang lingkupnya tidak mendominasikan. Padahal setiap negara memiliki karakter tersendiri yang mewakili cara mereka memandang sesuatu baik sebagai satu kesatuan maupun terpisah. 
126 Analisis Kebijakan Dan Pengelolaan Pendidikan Dasar terkait Standar Isi Di Sekolah Dasar - Fatma Khaulani, Sufyarma Marsidin, Ahmad Sabandi

DOI: 10.31004/edukatif.v2i2.112

Standar isi pendidikan Indonesia memang menjadi satu perhatian besar, karena menjadi panduan dalam mengarahkan dan memandu putra putri bangsa dalam menyongsong dan mempertahanakan negara Indonesia dari perkembangan globalisasi. Perlunya perencanaan suatu sistem pendidikan yang tidak hanya konsep semata, namun sesuai dengan pelaksanaan yang dapat dilakukan oleh segala komponen terutama siswa dalam mencapainya. Pendidikan tidak dapat lagi menentukan ketetapan baru namun masih bernuansa ketentuan yang lama, atau minimnya pembaharuan dalam setiap komponennya.

Ketidak efektifan dalam menjabarkan setiap komponen standar isi pendidikan akan membuat siswa sulit untuk memahami sesuatu pembelajaran, hal tersebut terbukti dari peringkat pendidikan Indonesia yang berada pada urutan 62 dari 72 negara di dunia. Menunjukkan buruknya sistem pendidikan di Indonesia termasik di dalamnya standar isi. Menunjukkan belum signifikannya dalam membangun peradaban bangsa Indonesia (Mustofa, 2017), sehingga kebutuhan akan jawaban bagaimana Indonesia pada masa depan belum dapat dicapai dan ditentukan dengan baik, sebatas sebagai seorang manusia.

\section{Analisis pembahasan Permendiknas No. 21 tahun 2016 tentang Standar Isi Dikdasmen terutama pendidikan masa depan.}

Makna akan adanya Pembentukan Permendikbut No. 21 Tahun 2016 mengenai Standar Isi Pendidikan Dasar dan Menengah, adalah kebutuhan dan keinginan Bangsa Indonesia dalam menjawab tantangan masa depan, melalui penerapan taksonomi Bloom yang direvisi oleh Anderson sebagai panduan dalam melaksanakan pendidikan di Indonesia terutama dalam mencapai standar kelulusan.

Karakteristik dari Permendikbud No. 21 Tahun 2016 adalah pengintegrasian dengan pelaksanaan kurikulum 2013, terutama pada jenjang pendidikan dasar yang pembelajaran dilakukan secara tematik terpadu yang menggunakan pendekatan saintifik, yaitu terdiri dari aktifitas pembelajaran mengamati, menanyakan, mengumpulkan informasi, mengolah informasi, dan menyampaikannya.

Bagi seorang pendidik standar isi adalah bagian yang sangat penting dan vital untuk dikembangkan karena dari penentuan standar isi maka akan menentukan kemana siswa itu akan diarahkan dan apa pencapaian masa depan setiap siswa berbasis kompetensi Abad 21.

Indonesia sebagai negara besar perlu mengetahui bagaimana karakter peserta didiknya untuk belajarr, terutama sebagai negara yang berada pada wilayah timur memiliki karakter sendiri yang membedakan cara pandang dengan teori-teori barat. Mengamati pada negara barat tidak akan sama prosesnya dan hasilnya di Indonesia sehingga perlu penjabaran yang optimal dalam menyesuaikan standar isi pendidikan dasar dengan keadaan dan karakter masyarakat Indonesia.

Pendidikan dasar di Indonesia salah satunya sekolah dasar memiliki beban standar isi yang cukup berat bagi siswa, jika dibandingkan dengan negara yang memiliki sistem pendidikan yang baik, seperti Negara Jepang, yang pada kelas 
127 Analisis Kebijakan Dan Pengelolaan Pendidikan Dasar terkait Standar Isi Di Sekolah Dasar - Fatma Khaulani, Sufyarma Marsidin, Ahmad Sabandi

DOI: 10.31004/edukatif.v2i2.112

rendahnya hanya diajarkan untuk membentuk sikap dan kemampuan-kemampuan dasar seperti penjumlahan dan penggurangan sederhana siswa dan kebutuhan dalam belajar pada jenjang pendidikan selanjutnya. Sedangkan di Indonesia pada awal masuk sekolah telah diajarkan perkalian dan pembagian. Hal tersebut menunjukkan standar isi yang ditawarkan belum sesuai dengan karakteristik siswa pada umur 7-8 tahun.

Perlu kita sadari bersama sisadari bahwa standar isi pendidikan harus sesuai dengan pelaksanaan dilapangan, banyak permasalahan dalam menguasi materi pembelajaran. Materi pembelajaran selama ini tidak melekat dengan kehidupan siswa, siswa menganggap materi untuk dihapal dan dipelajari di sekolah tanpa menghubungkan dengan kehidupan sehari-harinya. Sehingga dibutuhkan sebuah standar pendidikan yang tidak sekedar konsep belaka, namun sulit untuk dikuasai dan diterapkan di lapangan.

\section{KESIMPULAN}

Permendiknas No. 21 Tahun 2016 mengenai Standar Isi Pendidikan Dasar dan Menengah merupakan usaha pemerintah dalam menyeuaikan kebutuhan pendidikan Indonesia di masa depan terutama dalam mendukung golden era yang akan diperoleh Indonesia pada tahun 2045. Standar isi pada pertaturan tersebut merujuk pada penggunaan Teori Bloom dalam membentuk sikap, pengetahuan, dan keterampilan setiap peserta didik dengan menamati idiosinkrasi perkembangan dan kebutuhan peserta didik yang berada pada umur 712 tahun, berada pada perkembangan berpikir operasional konkrit. Menjadi perhatian kita semua adalah kebutuhan akan standar isi pendidikan dasar yang sesuai dengan pelaksanaan atau realita siswa dan kebutuhan adalah sesuatu yang mutlat untuk dimiliki oleh bangsa Indonesia. Karna melalui pendidikan yang baik tentu menghasilkan individu yang berkualitas dan keikut sertaan dalam mengembangkan peradaban dunia.

\section{DAFTAR PUSTAKA}

Haq, M. (2017). Analisis Standar Pengelolaan Pendidikan Dasar dan Menaengah. Jurnal Evaluasi, 1(1).

Kemenkeu. (2017). Membangun Generasi Berkualitas. Jurnal Media Keuangan Trasparansi Informasi Kebijakan Fiska, 12(119).

Mustofa. (2017). Pendidikan Islam Perspektif Humanisme-Pancasila. Jurnal Tarbiah, 24(1).

Oktaviani, N. \& W. (2019). Implementasi Standar Isi dalam Kurikulum 2013 di Sekolah Dasar. Jurnal Pajar, 3(6).

Permendikanas no 21. (2016). Standar Isi Pedidikan Dasar dan Menengah.

Riyana, C. (2010). Peningkatan Kopetensi Guru Melalui Penerapan Model Education Center Of Teacher Integrativ Virtual (Educative). Jurnal Penelitian Pendidikan, 11(1).

Widodo, H. (2015). Potret Pendidikandi Indonesia dan Kesiapan dalam Menghadapi Masyarakat Ekonomi Asean (MEA). Jurnal Cendekia, $13(2)$. 